\title{
Oxidative cyclization of alkenols with Oxone using a miniflow reactor
}

\author{
Yoichi M. A. Yamada ${ }^{1,2}$, Kaoru Torii ${ }^{2}$ and Yasuhiro Uozumi ${ }^{*}, 1,2$
}

\section{Preliminary Communication}

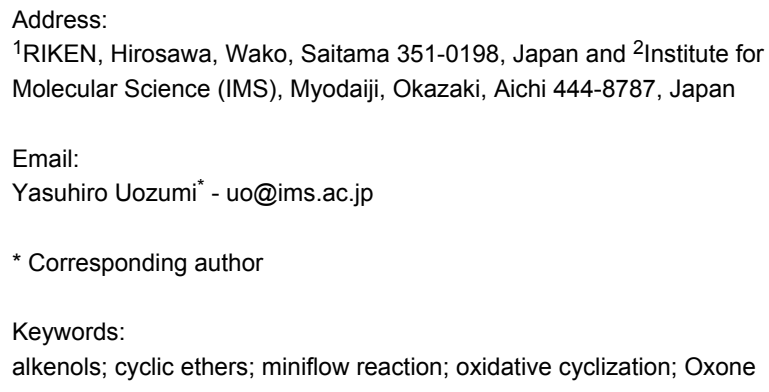

${ }^{1}$ RIKEN, Hirosawa, Wako, Saitama 351-0198, Japan and ${ }^{2}$ Institute for Molecular Science (IMS), Myodaiji, Okazaki, Aichi 444-8787, Japan

Email:

Yasuhiro Uozumi - uo@ims.ac.jp

* Corresponding author

Keywords:

alkenols; cyclic ethers; miniflow reaction; oxidative cyclization; Oxone

Beilstein Journal of Organic Chemistry 2009, 5, No. 18

doi: $10.3762 /$ bjoc. 5.18

Received: 13 March 2009

Accepted: 27 April 2009

Published: 29 April 2009

Guest Editor: A. Kirschning

(c) 2009 Yamada et al; licensee Beilstein-Institut.

License and terms: see end of document.

\begin{abstract}
A miniflow system for oxidative cyclization of alkenols with Oxone was developed. Thus, the oxidative cyclization of $(Z)$ - and $(E)$ alkenols in $i$-PrOH with an aqueous solution of Oxone proceeded smoothly and safely in a PTFE tube without any exogenous catalytic species, and was subsequently quenched in a flow-reaction manner to afford the corresponding furanyl and pyranyl carbinols quantitatively within 5 or $10 \mathrm{~min}$ of residence time.
\end{abstract}

\section{Introduction}

The development of flow-reaction systems for molecular transformations is an important goal in organic syntheses. Recently, innovative devices such as micro- and miniflow reactors that offer many fundamental as well as practical advantages for efficient organic transformations have been gaining ground in chemical experimentation [1-15]. Extensive investigations have revealed that the large interfacial area and the short molecular diffusion path in narrow space reactors often drastically improve the efficiency of a given chemical reaction. As a case in point, we have previously developed a catalyst-installed microflow reactor where a membranous polymeric palladium catalyst was deposited inside a micro-channel reactor at the laminar flow interface [16], resulting in the instantaneous production of biaryls (quantitative yield within $4 \mathrm{~s}$ of residence time) via a palladium-catalyzed Suzuki-Miyaura reaction under microflow conditions. An additional advantage of micro- and minireactors is the small heat capacity of the micro- and miniflow systems thus rendering exothermic and/or potentially explosive reactions safe and practical. Consequently, oxidative transformations with potentially explosive oxidants would be ideal target reactions for miniflow systems. We wish to report the oxidative construction of furanyl and pyranyl alkyl carbinols with Oxone via a miniflow reaction system.

\section{Results and Discussion}

Furanyl and pyranyl carbinols have generated considerable interest due to their presence in a number of therapeutically and biologically active compounds [17-31]. We therefore decided to 
Table 1: The oxidative cyclization of an alkenol 1a with Oxone under batch conditions.

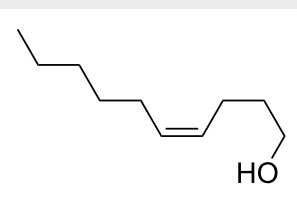

$1 \mathrm{a}$

oxidant

aq Oxone

$30 \%$ aq $\mathrm{H}_{2} \mathrm{O}_{2}$

polymeric $\mathrm{PW}_{12} \mathrm{O}_{40}{ }^{3-}$ (cat) with $30 \%$ aq $\mathrm{H}_{2} \mathrm{O}_{2}$ (see [32])

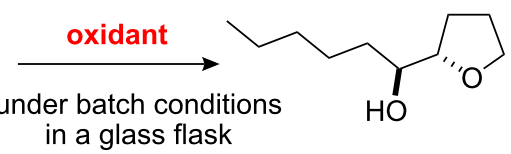

2a

conditions

$80^{\circ} \mathrm{C}, 5 \mathrm{~min}$

yield of $\mathbf{2 a}(\%)$

$80^{\circ} \mathrm{C}, 60 \mathrm{~min}$

$50{ }^{\circ} \mathrm{C}, 24 \mathrm{~h}$

99

no reaction

99 turn our attention to developing an oxidative cyclization of alkenols [32,33] for the preparation of furanyl and pyranyl alkyl carbinols. During our investigation, we found that the oxidative cyclization of (Z)-4-decen-1-ol (1a) with Oxone $\left(2 \mathrm{KHSO}_{5} \cdot \mathrm{KHSO}_{4} \cdot \mathrm{K}_{2} \mathrm{SO}_{4}\right)$ proceeded at $80{ }^{\circ} \mathrm{C}$ without any exogenous catalysts under small-scale batch conditions (up to $50 \mathrm{mmol}$ of 1a) to give threo-1-(2-tetrahydrofuranyl)hexan-1-ol (2a) in 99\% yield within 5 min (Table 1) [34]. When a mixture of an aqueous solution of Oxone $(100 \mathrm{mM}, 1 \mathrm{~mL}, 2$ equiv vs 1a) and a 2-propanol solution of $1 \mathbf{a}(50 \mathrm{mM}, 1 \mathrm{~mL})$ was stirred at $80{ }^{\circ} \mathrm{C}$ for $5 \mathrm{~min}$, the cyclization took place very smoothly to afford threo-1-(2-tetrahydrofuranyl)hexan-1-ol (2a) in 99\% yield as a single racemic diastereoisomer. Yet when $30 \%$ aq $\mathrm{H}_{2} \mathrm{O}_{2}$ was used as the oxidant at $80{ }^{\circ} \mathrm{C}$, the cyclization hardly proceeded at all, even with a longer reaction time [32]. We had previously found that a polymeric phosphotungstate catalyst promoted the cyclization of $1 \mathrm{a}$ with $30 \%$ aq $\mathrm{H}_{2} \mathrm{O}_{2}$ at $50{ }^{\circ} \mathrm{C}$ with a much longer reaction time $(24 \mathrm{~h})$. Thus, Oxone was found to be the most efficient oxidant to promote the cyclization of $(Z)$ 4-decen-1-ol (1a). Although a powerful and inexpensive oxidant for this transformation [35-42], Oxone however is also a known fire and explosion hazard [43] essentially rendering its large-scale use impractical. To avoid these potentially dangerous and hazardous conditions in a large-scale batch oxidation, we switched the conventional batch system to a miniflow system.

The miniflow reaction system is composed of poly(tetrafluoroethylene) (PTFE) tubes of $\varnothing=1 \mathrm{~mm}, \mathrm{~T}$-shaped connectors, and syringes with syringe pumps as shown in Figure 1. When the miniflow reaction of the alkenols $\mathbf{1}$ in $i$-PrOH with an aqueous solution of Oxone was carried out in the miniflow reactor with 5 min of residence time at $80^{\circ} \mathrm{C}$, we were pleased to see that the reaction proceeded smoothly to afford the corresponding cyclic ethers 2 in high conversion. Thus, a solution of an alkenol 1 in $i$-PrOH $(50 \mathrm{mM})$ and Oxone in water $(100 \mathrm{mM})$ were oppositely injected with a flow rate of $4.0 \mu 1 / \mathrm{min}$ each by using syringe pumps from the individual inlets. The mixed solution passed through a PTFE tube reactor (length $=50 \mathrm{~mm}$ ) at $80{ }^{\circ} \mathrm{C}$, and then was quenched with $30 \%$ aq $\mathrm{Na}_{2} \mathrm{~S}_{2} \mathrm{O}_{3}$ solution injected into the flow tube with a flow rate of $4.0 \mu \mathrm{l} / \mathrm{min}$. The resulting organic/aqueous outflow was collected in a glass vial. The chemical conversion and structure of the products were determined by GC and ${ }^{1} \mathrm{H}$ NMR analysis. As shown in Table 2,

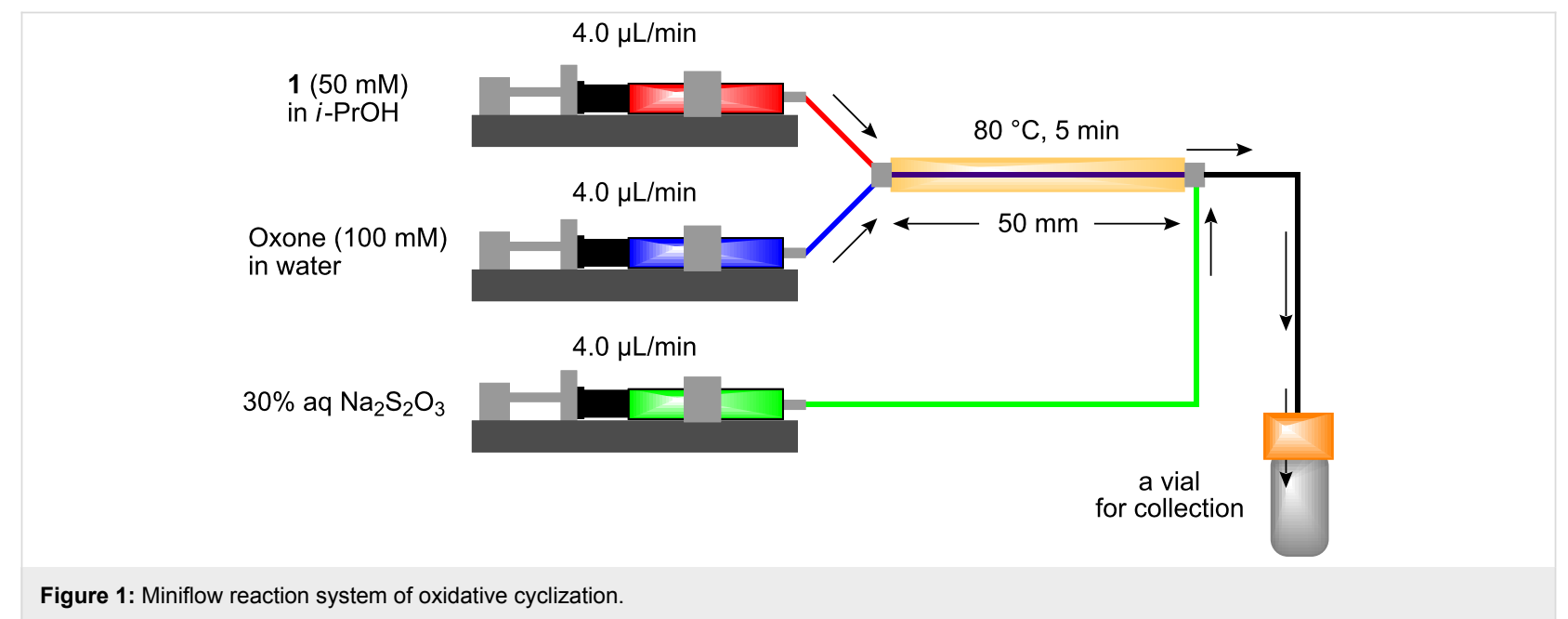


Table 2: Oxidative cyclization of alkenols with Oxone through a miniflow reactor. ${ }^{\text {a }}$

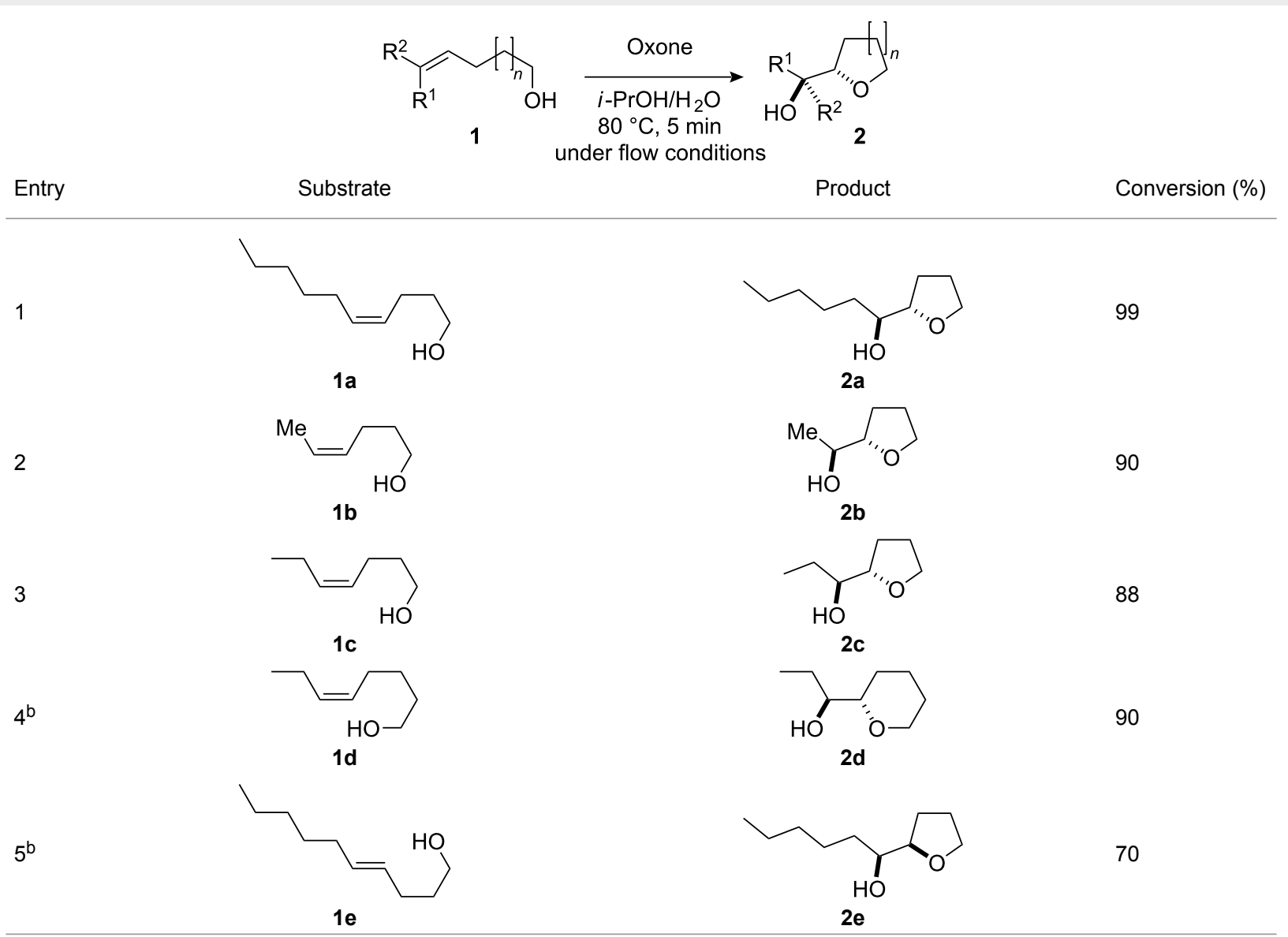

aalkenol $(50 \mathrm{mM}$ in $\mathrm{i}-\mathrm{PrOH})$, Oxone $\left(2 \mathrm{KHSO}_{5} \cdot \mathrm{KHSO}_{4} \cdot \mathrm{K}_{2} \mathrm{SO}_{4}\right)\left(100 \mathrm{mM}\right.$ in $\left.\mathrm{H}_{2} \mathrm{O}\right)$, flow rate: $4.0 \mu \mathrm{L} / \mathrm{min}$ each, $80^{\circ} \mathrm{C}$, residence time $=5 \mathrm{~min}$; several fractions were collected for each reaction shown to demonstrate the stable and high reactive performance of the miniflow reactor; the product $2 \mathrm{a}$ was obtained in $0.12 \mathrm{mmol} / \mathrm{h}$. b flow rate: $2.0 \mu \mathrm{L} / \mathrm{min}$ each, $80^{\circ} \mathrm{C}$, residence time $=10 \mathrm{~min}$.

entry 1 , the oxidative cyclization of $(Z)$-4-decen-1-ol (1a) with Oxone was performed within $5 \mathrm{~min}$ of residence time to afford threo-1-(2-tetrahydrofuranyl)hexan-1-ol (2a) in 99\% conversion. The cyclization of $(Z)$-4-hexen-1-ol (1b) and (Z)-4-hepten1-ol (1c) proceeded smoothly to give the threo-tetrahydrofuranyl alcohols $\mathbf{2 b}$ and $\mathbf{2 c}$ in $90 \%$ and $88 \%$ conversion, respectively (entries 2 and 3). This flow reaction system was also utilized for the formation of six-membered cyclic ethers. Thus, the oxidation of ( $Z$ )-5-octen-1-ol (1d) was carried out with a flow rate of $2.0 \mu \mathrm{L} / \mathrm{min}$ (residence time: $10 \mathrm{~min}$ ) to give $90 \%$ conversion of the threo-tetrahydropyranyl alcohol 2d (entry 4). (E)-4Decen-1-ol (1e) underwent oxidative cyclization with $10 \mathrm{~min}$ residence time to afford the erythro-product $2 \mathrm{e}$ in $70 \%$ conversion (entry 5). These stereochemical observations indicate that the cyclization involves a stereospecific reaction pathway. The reaction pathway of the present oxidative cyclization should proceed via the epoxidation of the alkene 1 with Oxone and subsequent oxirane ring opening with the intramolecular oxygen nucleophile (an intramolecular $\mathrm{S}_{\mathrm{N}} 2$ reaction) to afford the product 2 stereospecifically $[44,45]$. It should be noted that the miniflow cyclization of $1 \mathbf{a}$ was continuously carried out to give a quantitative conversion of $2 \mathbf{a}$ over $2 \mathrm{~h}$.

\section{Conclusion}

In conclusion, we have developed a miniflow reaction system for the oxidative cyclization of alkenols with Oxone, affording the corresponding cyclic ethers in high conversion, where potentially explosive Oxone was used and quenched safely. Development of instantaneous flow reaction systems for the oxidation reactions with a retention time of several seconds is currently in progress.

\section{Acknowledgments}

This work was supported by the GSC project, sponsored by the METI. We thank the JSPS (Grant-in-Aid for Scientific Research, no.15205015, no. 16790025, no.18065019 and no. 20655035), and the MEXT (Scientific Research on Priority Areas, no. 460) for partial financial support of this work. 


\section{References}

1. Yoshida, J.-i.; Nagaki, A.; Yamada, T. Chem.-Eur. J. 2008, 14, 7450-7459. doi:10.1002/chem.200800582 (See for reviews.)

2. Fukuyama, T.; Rahman, M. T.; Sato, M.; Ryu, I. Synlett 2008, 151-163. doi:10.1055/s-2007-1000884

3. Wiles, C.; Watts, P. Eur. J. Org. Chem. 2008, 1655-1671. doi:10.1002/ejoc.200701041

4. Kobayashi, J.; Mori, Y.; Kobayashi, S. Chem.-Asian J. 2006, 1, 22-35 doi:10.1002/asia.200600058

5. Jähnisch, K.; Hessel, V.; Löwe, H.; Baerns, M. Angew. Chem., Int. Ed. 2004, 43, 406-446. doi:10.1002/anie.200300577

6. Pennemann, H.; Hessel, V.; Löwe, H. Chem. Eng. Sci. 2004, 59, 4789-4794. doi:10.1016/j.ces.2004.07.049

7. Fletcher, P. D. I.; Haswell, S. J.; Pombo-Villar, E.; Warrington, B. H.; Watts, P.; Wong, S. Y. F.; Zhang, X. Tetrahedron 2002, 58, 4735-4754. doi:10.1016/S0040-4020(02)00432-5

8. Haswell, S. J.; Middleton, R. J.; O'Sullivan, B.; Skelton, V.; Watts, P.; Styring, P. Chem. Commun. 2001, 391-398. doi:10.1039/b008496o

9. Fukuyama, T.; Kobayashi, M.; Rahman, M. T.; Kamata, N.; Ryu, I. Org. Lett. 2008, 10, 533-536. doi:10.1021/ol702718z (See for selected examples.)

10. Hornung, C. H.; Mackley, M. R.; Baxendale, I. R.; Ley, S. V. Org. Process Res. Dev. 2007, 11, 399-405. doi:10.1021/op700015f

11. Sahoo, H. R.; Kralj, J. G.; Jensen, K. F. Angew. Chem., Int. Ed. 2007, 46, 5704-5708. doi:10.1002/anie.200701434

12. Tanaka, K.; Motomatsu, S.; Koyama, K.; Tanaka, S.; Fukase, K. Org. Lett. 2007, 9, 299-302. doi:10.1021/ol062777o

13. He, P.; Watts, P.; Marken, F.; Haswell, S. J. Angew. Chem., Int. Ed. 2006, 45, 4146-4149. doi:10.1002/anie.200600951

14. Nagaki, A.; Togai, M.; Suga, S.; Aoki, N.; Mae, K.; Yoshida, J. J. Am. Chem. Soc. 2005, 127, 11666-11675. doi:10.1021/ja0527424

15. Kawaguchi, T.; Miyata, H.; Ataka, K.; Mae, K.; Yoshida, J. Angew. Chem., Int. Ed. 2005, 44, 2413-2416. doi:10.1002/anie.200462466 (See for Swern oxidations by using a microflow system.)

16. Uozumi, Y.; Yamada, Y. M. A.; Beppu, T.; Fukuyama, N.; Ueno, M.; Kitamori, T. J. Am. Chem. Soc. 2006, 128, 15994-15995. doi:10.1021/ja066697r

17. Alali, F. Q.; Liu, X.-X.; Mclaughlin, J. L. J. Nat. Prod. 1999, 62, 504-540. doi:10.1021/np980406d

18. Hartung, J.; Greb, M. J. Organomet. Chem. 2002, 661, 67-84 doi:10.1016/S0022-328X(02)01807-7

19. Nakata, T.; Schmid, G.; Vranesic, B.; Okigawa, M.; Smith-Palmer, T.; Kishi, Y. J. Am. Chem. Soc. 1978, 100, 2933-2935. doi:10.1021/ja00477a081

20. Fukuyama, T.; Wang, C.-L. J.; Kishi, Y. J. Am. Chem. Soc. 1979, 101, 260-262. doi:10.1021/ja00495a065

21. Wuts, P. G. M.; D'Costa, R.; Butler, W. J. Org. Chem. 1984, 49, 2582-2588. doi:10.1021/jo00188a014

22. Still, W. C.; Romero, A. G. J. Am. Chem. Soc. 1986, 108, 2105-2106. doi:10.1021/ja00268a069

23. Boivin, T. L. B. Tetrahedron 1987, 43, 3309-3362. doi:10.1016/S0040-4020(01)81626-4
24. Evans, D. A.; Polniaszek, R. P.; Devries, K. M.; Guinn, D. E.; Mathre, D. J. J. Am. Chem. Soc. 1991, 113, 7613-7630. doi:10.1021/ja00020a025

25. Sinha, S.; Sinha-Bagchi, A.; Keinan, E. J. Am. Chem. Soc. 1995, 117, 1447-1448. doi:10.1021/ja00109a037 26. Koert, U. Synthesis 1995, 115-132. doi:10.1055/s-1995-3883

27. Sakaguchi, S.; Nishiyama, Y.; Ishii, Y.

J. Org. Chem. 1996, 61, 5307-5311. doi:10.1021/jo960275q

28. Towne, T. B.; McDonald, F. E. J. Am. Chem. Soc. 1997, 119, 6022-6028. doi:10.1021/ja962837t

29. Wang, Z.-M.; Tian, S.-K.; Shi, M. Tetrahedron Lett. 1999, 40, 977-980. doi:10.1016/S0040-4039(98)02577-5

30. Bhaumik, A.; Tatsumi, T. J. Catal. 2000, 189, 31-39. doi:10.1006/jcat.1999.2690

31. Ichihara, J.; Kambara, A.; Iteya, K.; Sugimoto, E.; Shinkawa, T.; Takaoka, A.; Yamaguchi, S.; Sasaki, Y. Green Chem. 2003, 5, 491-493. doi:10.1039/b303315e

32. Yamada, Y. M. A.; Guo, H.; Uozumi, Y. Org. Lett. 2007, 9, 1501-1504. doi:10.1021/ol070258v

33. Yamada, Y. M. A.; Guo, H.; Uozumi, Y. Heterocycles 2008, 76, 645-655. doi:10.3987/COM-08-S(N)56

34. Yamada, Y. M. A.; Torii, K.; Uozumi, Y. . Unpublished results.

35. Travis, B. R.; Sivakumar, M.; Hollist, G. O.; Borhan, B. Org. Lett. 2003, 5, 1031-1034. doi:10.1021/ol0340078 (See for examples of batch oxidation reactions with Oxone in the absence of catalysts.)

36. Curini, M.; Epifano, F.; Marcotullio, M. C.; Rosati, O. Synlett 1999, 777-779. doi:10.1055/s-1999-2703

37. Webb, K. S.; Levy, D. Tetrahedron Lett. 1995, 36, 5117-5118. doi:10.1016/0040-4039(95)00963-D

38. Denmark, S. E.; Forbes, D. C.; Hays, D. S.; DePue, J. S.; Wilde, R. G. J. Org. Chem. 1995, 60, 1391-1407. doi:10.1021/jo00110a049

39. Webb, S. B. Tetrahedron Lett. 1994, 35, 3457-3460. doi:10.1016/S0040-4039(00)73209-6

40. Davis, F. A.; Lal, S. G.; Durst, D. J. Org. Chem. 1988, 53, 5004-5007. doi:10.1021/jo00256a018

41. Trost, B. M.; Curran, D. P. Tetrahedron Lett. 1981, 22, 1287-1290. doi:10.1016/S0040-4039(01)90298-9

42. Kennedy, R. J.; Stock, A. M. J. Org. Chem. 1960, 25, 1901-1906. doi:10.1021/jo01081a019

43. See the MSDS (prepared by Du Pont Chemicals) for Oxone, a registered trademark of Du Pont Chemicals.

44. Misono, M. Chem. Commun. 2001, 1141-1152. doi:10.1039/b102573m

45. Mizuno, N.; Misono, M. Chem. Lett. 1987, 967-970. doi:10.1246/cl.1987.967 


\section{License and Terms}

This is an Open Access article under the terms of the Creative Commons Attribution License

(http://creativecommons.org/licenses/by/2.0), which permits unrestricted use, distribution, and reproduction in any medium, provided the original work is properly cited.

The license is subject to the Beilstein Journal of Organic Chemistry terms and conditions:

(http://www.beilstein-journals.org/bjoc)

The definitive version of this article is the electronic one which can be found at:

doi:10.3762/bjoc.5.18 